Original article

\title{
Influence of GSTP1 gene polymorhism on decreased semen quality
}

\author{
Galina I. Myandina, Alhejoj Hasan, Madina M. Azova, Ekaterina V. Tarasenko, Nina G. Kulchenko \\ Peoples' Friendship University of Russia (RUDN University), Moscow, Russia
}

Received 8 May 2019, Revised 20 September 2019, Accepted 19 November 2019

(C) 2019, Myandina G.I., Hasan A., Azova M.M., Tarasenko E.V., Kulchenko N.G.

(C) 2019, Russian Open Medical Journal

Abstract: Background - Genetic polymorphisms analysis of metabolic and antioxidant systems pathway genes are associated with male infertility is the most perspective and developed field in andrology.

Purpose - the aim of the research is to reveal the association of the glutathione S-transferase gene GSTP1 polymorphism C/T (rs1138272) with risk of pathospermia in Russian men in Moscow region.

Material and Methods - Case control study was conducted on 68 fertile men and 70 infertile men with various forms of pathospermia. Sperm analysis was performed according to WHO guidelines (WHO, 2010). DNA was extracted from peripheral blood leukocytes. Genotyping of the GSTP1 gene polymorphisms was carried out by generated amplicons from melting curve analysis after real time PCR. Results - statistically significant association of polymorphism GSTP1 C/T (Ala/Val; rs1138272) with asthenozoospermia ( $\chi 2=8.58, p=0.003$ ) and teratospermia $(\chi 2=6.81, p=0.009)$ risk was found. The frequencies of homozygous and heterozygous carries (CT+TT genotypes) for polymorphic locus GSTP1 gene ( $r$ 1138272) are 3 times higher for men with disturbance of motility of spermatozoa and 2.5 times higher for men with abnormalities in morphology of spermatozoa, then for men with normozoospermia.

Conclusion - The GSTP1 C>T polymorphism (rs1138272) associated with risk of teratospermia and asthenozoospermia in male of reproductive age.

Keywords: male infertility, GSTP1 gene, polymorphism, pathospermia, asthenozoospermia, teratospermia, oxidative stress.

Cite as Myandina GI, Hasan A, Azova MM, Tarasenko EV, Kulchenko NG. Influence of GSTP1 gene polymorhism on decreased semen quality. Russian Open Medical Journal 2019; 8: e0411.

Correspondence to Nina G. Kulchenko. Address: Peoples' Friendship University of Russia; 6, Miklukho-Maklaya str., Moscow, 117198, Russia. Phone: +79253444679. E-mail: kle kni@mail.ru.

\section{Introduction}

Approximately $17 \%$ of couples in Russia are not able to conceive spontaneously within 1 year of unprotected intercourses [1]. It is proven that male infertility factor is about $40-50 \%$ of couples's cases [2, 3]. It is known that impaired spermatogenesis is caused by chronic inflammatory diseases of prostate gland, varicocele, genital infections, sperm DNA fragmentation $[1,4-8]$. Pathogenic mechanisms of pathospermia do not only include bacterial infection, hypoxia of testis and damages of acrosomal formation, and also are caused by oxidative stress development [7, 9-11]. Oxidative stress (OS) is believed to be an important cause of idiopatic male infertility [5, 11, 12]. As usual, reactive oxygen species (ROS) originate from cellular metabolism of oxygen and normally are neutralized by homeostatic antioxidant systems of humans [9]. The enzymatic antioxidant systems in human seminal plasma are a group of enzymes that include glutation peroxidase 1 (GXP1) and glutation S-transferase (GST), manganese superoxide dismutase (SOD2) and catalase (CAT) [13]. Oxidative stress is caused by imbalance of antioxidant enzymes and level of ROS [14]. Besides, morphologically anomalous sperm has an increased ability to generate reactive oxygen species (ROS) and demonstrates low antioxidant activity [12].
Genetic polymorphisms analysis of metabolic and antioxidant systems pathway genes is associated with male infertility is the most perspective and developed field in andrology $[10,15]$. There several available studies prove the association of GSTP1 gene polymorphism with male infertility in Asians [15-17]. Some findings are devoted for study the association of GSTP polymorphism and infertility in men used cigarette smoke $[18,19]$.

The aim of the research is to reveal the association of the glutation S-transferase gene GSTP1 polymorphism C/T (rs1138272) with risk of pathospermia in Russian men in Moscow region.

\section{Material and Methods}

The study includes men living in the Moscow region $(n=138)$ : of these, 70 men with impaired reproductive function with various forms of pathospermia of unknown etiology (the $1^{\text {st }}$ group of patients) and 68 fertile men of comparable age $\left(2^{\text {nd }}\right.$ group of patients). The $1^{\text {st }}$ group includes men with abnormal spermiogram, infertility history more than one year, excluded infertility in spouse. The $2^{\text {nd }}$ group includes men with normal sperm parameters have one or more children. For both groups we excluded patients under 18 years old, with genital infections, with varicocele, hydrocele and chronic inflammatory diseases of 
prostate gland. Informed consent was taken for all participants before study.

All patients underwent a preliminary clinical examination: collection of complaints, anamnesis, examination of objective and urological status, spermogram analysis (WHO, 2010), study of the hormonal profile and karyotype and the presence of deletions in the AZF region of Y-chromosome, mutations in the CFTR gene.

DNA was isolated from leukocyte mass using DNA expressblood kits produced by Synthol (Russia). Genotyping of the GSTP1 gene polymorphism Ala114Val (rs1138272) was performed by generation of amplicons from melting curve analysis after real time PCR (RT-PCR). It was used the amplifier CFX96 (Bio-Rad) with software program CFX Manager TM for genotyping of the GSTP1 gene polymorphism.

Quantitative data are presented as mean and standard deviation - M $\pm S D$, binary (such as "yes/no") variables - as frequencies in absolute values and in percentage - no. (\%). The correlation between the carrier of one or another allele and the incidence rate was determined by criterion $\chi^{2}, 95 \% \mathrm{Cl}$ (confidence interval). The obtained data was processed using the STATISTICA 6.0 software package (StatSoft, USA). The differences were considered significant at $p<0.05$.

\section{Results}

Clinical profile of patients in both groups of participant subjects is shown in Table 1.

Mean age was $29.5 \pm 3.8$ among all patients. The average body mass index was $20.4 \pm 4.4 \mathrm{~kg} / \mathrm{m}^{2}$. The most part of all participant subjects abuses cigarette smoking. No significant differences were observed between the first and second groups of patients with respect to hormonal levels. Consequently, the both groups of patients were concordant with their clinical profile.

Seminal parameters of patients (first group) and fertile men (second group) are shown in Table 2. We found statistically significant differences between the first and second groups of patients with respect to maintenance of morphologically abnormal spermatozoa and quantity of motility active spermatozoa.

All patients had a normal karyotype, no mutations in the CFTR gene, and no AZF micro deletions on the $Y$ chromosome were found. Consequently, the data obtained for men with abnormalities in sperm parameters $(n=70)$ were designed as idiopathic infertility.

The frequencies of genotypes GSTP1 polymorphism C>T in groups of participant subjects are shown in Table 3 . The frequencies of the CC, СТ $и$ TT genotypes GSTP1 (Ala/Val) (C>T, rs1138272) polymorphism were $70.0 \%, 27.1 \%$ и $30.0 \%$ for the patients with infertility and $83.8 \%, 16.2 \%$ n $0 \%$, respectively, in the group of fertile men $(p=0.095)$. As homozygous genotype TT ( $r$ 1138272) was not detected in healthy control and it was in low frequency in infertile men (0.03), heterozygous and homozygous carries of allele $\mathrm{T}(114 \mathrm{Val})$ were allocated to the separate group (genotype CT+TT; Ala/Val+Val/Val). Carriers of the genotype CT+TT (Ala/Val+Val/Val) in men with pathospermia met with a frequency of $30.0 \%$, in the group of fertile men the frequency of carriers of genotype $(C T+T T)$ was $16.2 \%(p=0.050)$. The frequencies of the genotypes GSTP1 polymorphism (Ala114Val; C $>$ T) among the men with the pathospermia and healthy control group show no statistically significant differences ( $p>0.05$ ).
Table 1. Clinical profile of patients in both groups

\begin{tabular}{|c|c|c|c|}
\hline \multirow[t]{2}{*}{ Clinical profile } & \multicolumn{3}{|c|}{ Groups of patients } \\
\hline & $\begin{array}{c}1_{(n=70)}{ }^{s t} \text { group } \\
\end{array}$ & $\begin{array}{c}2_{(n=68)}^{\text {group }} \\
\end{array}$ & p-level \\
\hline Age, years & $30.0 \pm 2.4$ & $27.0 \pm 4.9$ & 0.154 \\
\hline Cigarette smoking & $41(58.5)$ & $38(55.8)$ & 0.147 \\
\hline Consumption of alcohol & $15(21.4)$ & $18(26.4)$ & 0.276 \\
\hline Body mass index $\left(\mathrm{kg} / \mathrm{m}^{2}\right)$ & $20.2 \pm 4.6$ & $19.7 \pm 5.1$ & 0.860 \\
\hline Hormonal FSH, ME/ml & $2.4 \pm 1.6$ & $3.1 \pm 1.4$ & 0.740 \\
\hline $\mathrm{LH}, \mathrm{ME} / \mathrm{ml}$ & $4.1 \pm 0.9$ & $3.9 \pm 1.1$ & 0.811 \\
\hline Testosterone, $\mathrm{ng} / \mathrm{ml}$ & $14.2 \pm 1.3$ & $12.9 \pm 0.8$ & 0.120 \\
\hline Prolactin, ME/ml & $6.9 \pm 2.3$ & $5.6 \pm 1.9$ & 0.943 \\
\hline
\end{tabular}

Quantitative data are presented as mean with standard deviation - $\mathrm{M} \pm \mathrm{SD}$,

binary (such as "yes/no") variables - as frequencies in absolute values and in percentage - no. (\%).

$\mathrm{FSH}$, follicle stimulating hormone; LH, luteinizing hormone.

Table 2. Seminal parameters in patients of the first and second groups (mean \pm SD)

\begin{tabular}{lccr}
\multicolumn{1}{c}{ Seminal parameters } & \multicolumn{3}{c}{ Groups of patients } \\
& $\begin{array}{c}1^{\text {st }} \text { group } \\
(\mathrm{n}=70)\end{array}$ & $\begin{array}{c}2^{\text {nd }} \text { group } \\
(\mathrm{n}=68)\end{array}$ & $\mathrm{p}$-level \\
\hline Ejaculate volume, $\mathrm{ml}$ & $3.8 \pm 1.3$ & $4.2 \pm 1.0$ & 0.071 \\
$\mathrm{pH}$ & $7.3 \pm 0.1$ & $7.4 \pm 0.1$ & 0.083 \\
Sperm concentration, $\times 10^{6} / \mathrm{ml}$ & $4.5 \pm 2.4$ & $29.7 \pm 12.8$ & $<0.001$ \\
Motility, $\%$ & $18.6 \pm 6.2$ & $29.6 \pm 0.8$ & 0.012 \\
Normal morphology, $\%$ & $1.2 \pm 0.8$ & $5.6 \pm 2.5$ & 0.014 \\
Leucocytes, $\mathrm{x} 10^{6} / \mathrm{ml}$ & $0.34 \pm 0.21$ & $0.52 \pm 0.17$ & 0.160 \\
\hline
\end{tabular}

Data are presented as mean with standard deviation $-\mathrm{M} \pm \mathrm{SD}$.

Table 3. Distribution of GSTP1 genotypes among infertile patients and fertile men $(n=138)$

\begin{tabular}{|c|c|c|c|c|}
\hline \multirow[t]{3}{*}{ Groups of study } & \multicolumn{4}{|c|}{ Genotype } \\
\hline & (Ala/Ala) & (Ala/Val) & (Val/Val) & (Ala/Val + \\
\hline & $\mathrm{CC}$ & $\mathrm{CT}$ & TT & $\mathrm{Val} / \mathrm{Val}) \mathrm{CT}+\mathrm{TT}$ \\
\hline Infertile men $(n=70)$ & $49(70.0)$ & $19(27.1)$ & $2(2.9)$ & $21(30.0)$ \\
\hline Fertile men $(n=68)$ & $57(83.8)$ & $11(16.2)$ & $0(0)$ & $11(16.2)$ \\
\hline$\chi^{2}$ & & 4.70 & & 3.70 \\
\hline p-level & & 0.095 & & 0.050 \\
\hline
\end{tabular}

Binary data are presented as frequencies in absolute values and in percentage - no. (\%).

Table 4. Distribution of genotypes frequencies for GSTP1 polymorphism (C>T; Ala/Val) (rs 1138272) in studied subgroups of patients with different parameters of spermogram

\begin{tabular}{llccccc}
\hline $\begin{array}{l}\text { Parameters } \\
\text { of spermograms } \\
\text { in studied groups }\end{array}$ & $\begin{array}{c}\text { (Ala/Ala) } \\
\text { CC }\end{array}$ & $\begin{array}{c}\text { (Ala/Val) } \\
\text { CT }\end{array}$ & $\begin{array}{c}\text { (Val/Val) } \\
\text { Tा }\end{array}$ & $\begin{array}{c}\text { (Ala/Val + } \\
\text { Val/Val) } \\
\text { CT+TT }\end{array}$ & $\begin{array}{c}\text { p- } \\
\text { level }\end{array}$ \\
\hline $\begin{array}{l}\text { Infertile } \\
\text { men }\end{array}$ & $\begin{array}{l}\text { Asthenozoo } \\
\text { spermia (n=26) }\end{array}$ & $15(57.9)$ & $10(38.4)$ & $1(3.7)$ & $11(42.3)$ & 0.014 \\
& $\begin{array}{l}\text { Teratozoo } \\
\text { spermia (n=21) }\end{array}$ & $13(61.9)$ & $7(33.3)$ & $1(4.8)$ & $8(38.0)$ & 0.037 \\
& $\begin{array}{l}\text { Azoospermia } \\
\text { (n=23) }\end{array}$ & $21(91.3)$ & $2(8.7)$ & $0(0)$ & $2(8.7)$ & 0.734 \\
\hline $\begin{array}{l}\text { Healthy } \\
\text { men }\end{array}$ & $\begin{array}{l}\text { Normozoo } \\
\text { spermia (n=68) }\end{array}$ & $57(83.8)$ & $11(16.2)$ & $0(0)$ & $11(16.2)$ & 0.775 \\
\hline
\end{tabular}

Binary data are presented as frequencies in absolute values and in percentage - no. (\%). 
Further, a comparative analysis of the genotypes frequencies in subgroups of men with different parameters of spermogram was carried out on the studied GSTP1 polymorphism (Ala114Val; rs 1138272); the results are shown in Table 4.

Statistically significant differences were found for the genotypes frequencies of GSTP1 polymorphism (C>T; rs1138272) in men with asthenospermia and teratospermia. The frequencies of genotypes CC, CT TT in men with asthenozoospermia was $57.9 \%, 38.4 \%$ and $3.7 \%\left(\chi^{2}=8.47, p=0.014\right)$; and in men with teratospermia $-61.9 \%, 33.3 \%$ n $4.8 \% \quad\left(\chi^{2}=6.55, p=0.037\right)$. The frequencies of homozygous and heterozygous carries of GSTP1 polymorphism (genotypes $\mathrm{CT}+\mathrm{TT}$ ) are three times higher in the case of sperm motility impairment $\left(\chi^{2}=7.16, p=0.007\right)$, and 2.5 times higher in the case of disrupted morphology of the sperm cells $\left(\chi^{2}=4.6, p=0.032\right)$.

\section{Discussion}

Male infertility is multifactorial disease associated with individual genetic background $[3,8,10]$. The studies of foreign authors demonstrate that quality of sperm has decreased in the last decades all over the world [2]. This fact manly is believed to be a result of unbalanced diet, adverse environment factors and poor lifestyle, which cause oxidative stress [2,9]. According to data of many authors oxidative stress is demonstrated to $50 \%$ of men with confirmed infertility $[1,5,11,12]$. Human ejaculate has been shown to contain a significant amount of glutation S-transferases, which can weaken the ROS toxity to sperm [20]. Weakness of antioxidant glutation S-transferase enzymes may lead to high sensitivity of cells to damages factors of environment and consequently to be involved in many pathogenic mechanisms, including infertility [15]. Free radicals can damage sperm DNA directly by interacting with purine and pyrimidine bases, or cause lipid peroxidation, membrane fluidity and sperm motility reduction and apoptosis $[5,15,20]$.

In meta analysis of Safarinjad et al. (2012) it was noted that only two studies were carried out before 2012 to reveal the association GSTP1 polymorphisms with male infertility [15]. In Europe population it was identified an association between GSTP1 polymorphisms and abnormalities in sperm parameters in infertile men in Spain [21]. It is necessary to note that few studies have been carried out to clarify the association of GSTP1 polymorphism with risk of pathospermia but these relationships are still controversial [16, 22]. Nguen et.al. (2018) have reported that the GSTP1 polymorphisms (rs1138272 and rs1695) associated with male infertility in subjects from Vietnam [16]. Early studies have been conducted in Chine did not reveal the association between GSTP1 polymorphisms and pathospermia (odds ratio (OR) 0.86 , 95\%Cl: 0.60-1.25, $\chi^{2}=0.197, p=0.657$ ) [23]. Later Xiong et al. (2015) have identified the association of GSTP1 polymorphisms with high risk of male infertility (OR 1.53, 95\%Cl: 1.11-2.11, $\mathrm{p}=0.009$ ) [17]. The data obtained by Feng et al. (2015) have confirmed the association between GSTP1 polymorphisms and infertility in men with azoospermia (OR 1.58, 95\%Cl: 1.13-2.21, $\chi^{2}=13.60, p<0.001$ ) [24].

Our findings reveal that the frequencies of GSTP1 genotype did not differ significantly among infertile patients and healthy control $(p>0.05)$, but in subgroups in patients with abnormal sperm parameters (asthenozoospermia and teratospermia) the frequencies of GSTP1 genotypes differed significantly $(p<0.05)$. That means that patients with sperm motility impairment and disrupted morphology of the sperm cells are in high risk of oxidative stress. The results of this study concordant with findings of other authors state that oxidative stress is caused by reduction of antioxidant enzymes activity due the polymorphisms of antioxidant systems genes and it affects the spermatozoa worsening their fertility [15, 21].

Detection of point mutation for men with infertility should be applied in preliminary clinical examination for medical correction of spermatogenesis and for successful assistant reproductive technology.

\section{Conclusion}

The GSTP1 polymorphism (Ala/Val) (C>T, rs1138272) associates with male infertility. The frequencies of homozygous and heterozygous carries of GSTP1 polymorphism (Ala/Val; C $>$ T), are three times higher in men with asthenozoospermia, and 2.5 times higher in men with teratozoospermia. These patients are in high risk of oxidative stress and need early medical correction.

\section{Limitations}

We should acknowledge that limitation of this study is the small size of infertile men and healthy control groups. Further studies should be conducted on a larger scale to explore the association of GSTP1 polymorphisms with male infertility with men from different ethnic groups. Second, we have not considered gene-environment interaction in our study.

\section{Ethical approval}

The study was done in accordance with the standards of Good Clinical Practice and principles of Helsinki Declaration. The study was approved by the Bioethics Committee of Peoples' Friendship University of Russia (Moscow, Russia).

\section{Conflict of interest}

The authors declare no conflict of interest.

\section{Funding information}

The publication was prepared with the support of the "RUDN University Programm 5-100".

\section{References}

1. Bozhedomov VA, Vinogradov IV, Lipatova NA, Rokhlikov IM, Tretyakov AA, Nikolaeva MA. Childless marriage: role of male factor (clinical and organizational-and-methodical aspects). Obstetrics and Gynecology 2014; (1): 70-77. Russian. https://elibrary.ru/item.asp?id=21313798.

2. Lipovac M, Bodner F, Imhof M, Chedraui P. Comparison of the effect of a combination of eight micronutrients versus a standard mono preparation on sperm parameters. Reprod Biol Endocrinol 2016; 14(1): 84. https://doi.org/10.1186/s12958-016-0219-0.

3. Druzhinina NK, Korovyakova EM. Male infertility. Genetic aspects. Bulletin "Biomedicine and sociology" 2018; 3(4): 49-51. Russian. https://elibrary.ru/item.asp?id=36703436.

4. Lewis SE, John Aitken R, Conner SJ, luliis GD, Evenson DP, Henkel R, et al. The impact of sperm DNA damage in assisted conception and beyond: recent advances in diagnosis and treatment. Reprod Biomed Online 2013; 27(4): 325-337. https://doi.org/10.1016/i.rbmo.2013.06.014.

5. Kulchenko NG. Oxidative stress in the development of non-obstructive azoospermia. Trudny Patient 2017; 15(4-5): 44-46. Russian. https://elibrary.ru/item.asp?id=30040881. 
6. Pimenov EP, Andryukhin MI. The role of DNA fragmentation in the pathogenesis of male infertility. Bulletin "Biomedicine and sociology" 2019; 4(1): 38-41. Russian. https://elibrary.ru/item.asp?id=36703458

7. Taktarov VG, Strachuk AG, Gushchina YuSh, Korovyakova EA, Pashin SS, Freire Da Sivla T. Treatment of male infertility in varicocele. Clinical observation. Trudny Patient 2018; 1611): 64-66. Russian. https://doi.org/10.24411/2074-1995-2018-10035.

8. Kalinycheva GE, Karaseva NV. Microdeletions in the AZF regions of the gene with male infertility. Bulletin "Biomedicine and sociology" 2018; 3(4): 56-59. Russian. https://elibrary.ru/item.asp?id=36703438.

9. Bonanno O, Romeo G, Asero P, Pezzino FM, Castiglione R, Burrello N, et al. Sperm of patients with severe asthenozoospermia show biochemical, molecular and genomic alterations. Reproduction 2016; 152(6): 695-704. https://doi.org/10.1530/REP-16-0342.

10. Myandina GI, Kulchenko NG, Alhejoj H. Polymorphism G-105A SEPS1 gene and mens' infertility. Medical News of North Caucasus 2018; 13(3): 488-490. https://doi.org/10.14300/mnnc.2018.13085.

11. Vinogradov IV, Zhivulko AR, Vinogradova LM, Korolev SV. Docosahexaenoic acid in the treatment of male infertility. Andrology and Genital Surgery 2018; 19(4): 21-27. Russian. https://doi.org/10.17650/2070-9781-2018-19-4-21-27.

12. Charagozloo P, Aitken RJ. The role of sperm oxidative stress in male infertility and significance of oral antioxidant therapy. Hum Reprod 2011; 26(7): 1628-1640. https://doi.org/10.1093/humrep/der132.

13. O'Flaherty C. The enzymatic antioxidant system of human spermatozoa. Advances in Andrology 2014; 2014: 626374. https://doi.org/10.1155/2014/626374.

14. Dattilo $M, D^{\prime}$ Amato $G$, Caroppo $E$, Ménézo $Y$. Improvement of gamete quality by stimulating and feeding the endogenous antioxidant system: mechanisms, clinical results, insights on gene-environment interactions and the role of diet. J Assist Reprod Genet 2016; 33(12): 1633-1648 https://doi.org/10.1007/s10815-016-0840-z.

15. Safarinejad MR, Dadkhah F, Ali Asgari M, Hosseini SY, Kolahi AA, IranPour E. Glutathione S-transferase polymorphisms (GSTM1, GSTT1, GSTP1) and male factor infertility risk: a pooled analysis of studies. Urol J 2012; 9(3): 541-548. https://www.ncbi.nlm.nih.gov/pubmed/22903474.

16. Trang NT, Huyen VT, Tuan NT, Phan TD. Association of Nacetyltransferase-2 and glutathion S-transferase polymorphisms with idiopathic male infertility in Vietnam male subjects. Chem Biol Interact 2018; 286: 11-16. https://doi.org/10.1016/j.cbi.2018.03.001.

17. Xiong $\mathrm{DK}$, Chen $\mathrm{HH}$, Ding $\mathrm{XP}$, Zhang $\mathrm{SH}$, Zhang JH. Association of polymorphisms in glutathione S-transferase genes (GSTM1, GSTT1, GSTP1) with idiopathic azoospermia or oligospermia in Sichuan, China. Asian J Androl 2015; 17(3): 481-486. https://doi.org/10.4103/1008682X.143737.

18. Yarosh SL, Kokhtenko EV, Churnosov MI, Solodilova MA, Polonikov AV. Joint effect of glutathione S-transferase genotypes and cigarette smoking on idiopathic male infertility. Andrologia 2015; 47(9): 980986. https://doi.org/10.1111/and.12367.

19. Hekim N, Gure MA, Metin Mahmutoglu A, Gunes S, Asci R, Henkel R SNP's in xenobiotic metabolism and male infertility. Xenobiotica 2019: 1-8. https://doi.org/10.1080/00498254.2019.1616850.

20. Kao SH, Chao HT, Chen HW, Hwang TI, Liao TL, Wei YH. Oxidative stress in human sperm with lower motility. Fertil Steril 2008; 89(5): 11831190. https://doi.org/10.1016/i.fertnstert.2007.05.029.

21. García Rodríguez A, de la Casa M, Johnston S, Gosálvez J, Roy R. Association of polymorphisms in genes coding for antioxidant enzymes and human male infertility. Ann Hum Genet 2018; 83(1): 63-72. https://doi.org/10.1111/ahg.12286.

22. Tang $K$, Xue $W$, Xing $Y, X u S, W u$, Liu R, et.al. Genetic polymorphisms of glutathione $\mathrm{S}$-transferase $\mathrm{M} 1, \mathrm{~T} 1$, and $\mathrm{P} 1$, and the assessment of oxidative damage in infertile men with varicoceles from northwestern China. J Androl 2012; 33(2): 257-263. https://doi.org/10.2164/jandrol.110.012468.

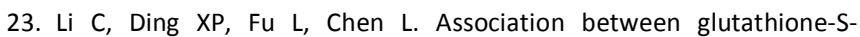
transferase gene polymorphisms (GSTM1, GSTT1 and GSTP1) and idiopathic azoospermia. Zhonghua Yi Xue Yi Chuan Xue Za Zhi 2013; 30(1): 102-105. Chinese. https://doi.org/10.3760/cma.j.issn.10039406.2013.01.025.

24. Feng Z, Jing Z, Liu H, Liao S, Guo L, Mao C, et al. Association of SPO11 and GST gene polymorphisms with idiopathic male infertility in ethnic Han Chinese. Zhonghua Yi Xue Yi Chuan Xue Za Zhi 2015; 32(6): 866 870. https://doi.org/10.3760/cma.j.issn.1003-9406.2015.06.025.

\section{Authors:}

Galina I. Myandina - DSc (Biol.), Professor, Department of Biology and General Genetics, Peoples' Friendship University of Russia, Moscow, Russia. https://orcid.org/0000-0002-7613-326X.

Alhejoj Hasan - Post-graduate student, Department of Biology and General Genetics, Peoples' Friendship University of Russia, Moscow, Russia. https://orcid.org/0000-0001-6924-1679.

Madina M. Azova - DSc (Biol.), Professor, Head of the Department of Biology and General Genetics, Peoples' Friendship University of Russia, Moscow, Russia. https://orcid.org/0000-0002-7290-1196.

Ekaterina V. Tarasenko - PhD (Biol.), Associate Professor, Department of Biology and General Genetics, Peoples' Friendship University of Russia, Moscow, Russia. https://orcid.org/0000-0002-0665-9741.

Nina G. Kulchenko - PhD (Med), Urologist, Doctor of ultrasonic diagnostics, Senior Lectures of the Department of Histology, Cytology and Embryology, Peoples' Friendship University of Russia, Moscow, Russia. https://orcid.org/0000-0002-4468-3670. 